\title{
ISLAM DAN HAK KESIHATAN REPRODUKTIF WANITA BERKAHWIN: SATU SOROTAN LITERATUR
}

\section{Islam and Married Women's Reproductive Rights: A Literature Review}

\author{
Norhana Ahad \\ PhD Candidate, Department of Shariah and Law, \\ Academy of Islamic Studies, \\ University of Malaya, 50603 Kuala Lumpur. \\ norhanaahad1988@gmail.com \\ Raihanah Hj. Abdullah \\ Professor, Department of Shariah and Law, \\ Academy of Islamic Studies, \\ University of Malaya, 50603 Kuala Lumpur. \\ raihanah@um.edu.my
}

\begin{abstract}
The issue of women's reproductive rights is not something new to the society. Nevertheless, their knowledge and practice with regard to this matter is still in a polemic circle, since misunderstandings and ignorance can still be spotted among the society in empowering reproductive rights. The forthcoming potential encounters and challenges from various parties have drawn the current status of women's reproductive rights to be at a disadvantageous level. This writing will highlight on previous studies which discussed on women's reproductive rights, be it in the argument of Shariah or through local practices or the ones in western countries. However, this writing focuses more on the reproductive rights of married women, as it is recognized that they need to live in a larger and complex frame of reproductive role. Hence, it is the responsibility of all parties to ensure that this
\end{abstract}


group obtains the justice to avoid oppression and negligence of each role of reproductive rights of married woman.

Keywords: reproductive rights, reproductive health, married women's reproductive rights

\section{PENDAHULUAN}

Kedatangan Islam telah meletakkan wanita pada kedudukan dan taraf yang seiring dengan lelaki, persamaan dalam aspek kemanusiaan, tanggungjawab, peluang memperoleh ganjaran dan balasan daripada Allah SWT. Setiap penghormatan itu turut dilihat apabila al-Quran sendiri menamakan salah satu dari surah-surahnya dengan nama al-Nisā’ yang membawa maksud wanita. Kemuliaan terhadap wanita turut disertai dengan hak-hak keistimewaan yang telah dijanjikan oleh agama sebagaimana terkandung dalam lipatan sejarah Islam yang tercatat hingga kini (al-Būṭ̂̄, 1991: 330).

Berbicara tentang hak wanita, tidak semestinya hak itu dinilai melalui aspek perkahwinan, dan kehartaan semata, tetapi ianya mempunyai perbincangan yang lebih mendalam khususnya hak wanita dalam mencapai tahap kesihatan seksual dan reproduktif yang tinggi, seperti membuat keputusan dalam perihal perkahwinan, keibuan, perancangan keluarga dan kontraseptif. Secara tidak langsung perbincangan ini akan berkaitan dengan aspek kesihatan reproduktif dan juga seksual. Aspek-aspek ini merangkumi lelaki dan wanita tetapi ianya lebih sinonim dengan wanita memandangkan wanita mempunyai peranan yang lebih kompleks apabila terpaksa melalui proses khusus kehamilan, kelahiran dan penyusuan anak (Harlina, 2009: 66).

Hak reproduktif wanita telah menjadi perkara yang mendapat perhatian di peringkat antarabangsa sejak beberapa tahun kebelakangan. Pada dasarnya, hak reproduktif wanita ini merupakan suatu perkembangan yang lahir dari konsep hak asasi manusia yang diperjuangkan suatu ketika. Secara umumnya, ianya boleh dibahagikan dari dua sisi keutamaan, di mana setiap manusia yang lahir itu memiliki hak individu yang tersendiri, yang takkan terpisah daripada individu itu sendiri. Keduanya adalah hak seseorang individu yang terjamin oleh kewajipan negara dan masyarakat sekelilingnya. Justeru hak reproduktif wanita ini akan mencakupi setiap hak asasi manusia yang diakui oleh dasar negara dan juga syariat Islam sendiri melalui pelbagai deklarasi-deklarasi yang tertentu.

Golongan wanita yang berkahwin dan belum berkahwin, keduaduanya memiliki peranan tersendiri. Walau bagaimanapun, tuntutan bagi 
golongan wanita yang berkahwin adalah sedikit kompleks berbanding yang belum berkahwin, sama ada dari segi tanggungjawab, mahupun kitaran reproduktif mereka. Wanita yang sudah berkahwin lebih terdedah kepada pengabaian hak reproduktif wanita kerana proses-proses yang mereka perlu lalui dalam menjalani kehidupan seharian dan memenuhi tuntutan kapasiti seorang isteri mahupun ibu. Justeru suatu pemahaman semasa sangat perlu dalam memberikan kesedaran kepada golongan wanita berkahwin ini akan kepentingan hak kesihatan reproduktif wanita. Kesedaran ini sangat perlu kerana akan memberikan satu kekuatan pada golongan wanita berkahwin ini, agar sentiasa mempersiapkan diri mereka dengan ilmu pengetahuan yang mencukupi supaya tidak lagi berlaku penindasan mahupun pengabaianpengabaian terhadap amalan hak kesihatan reproduktif wanita seperti mendapatkan amalan seksualiti rumah tangga yang selamat, perancangan keluarga, serta bebas dari keganasan rumah tangga.

Justeru, penulisan melalui sorotan literatur ini serba sedikit mengetengahkan terlebih dahulu akan konsep asas berkaitan hak kesihatan reproduktif wanita. Penulisan ini dibahagikan kepada empat tema sebagaimana dalam rajah berikut:

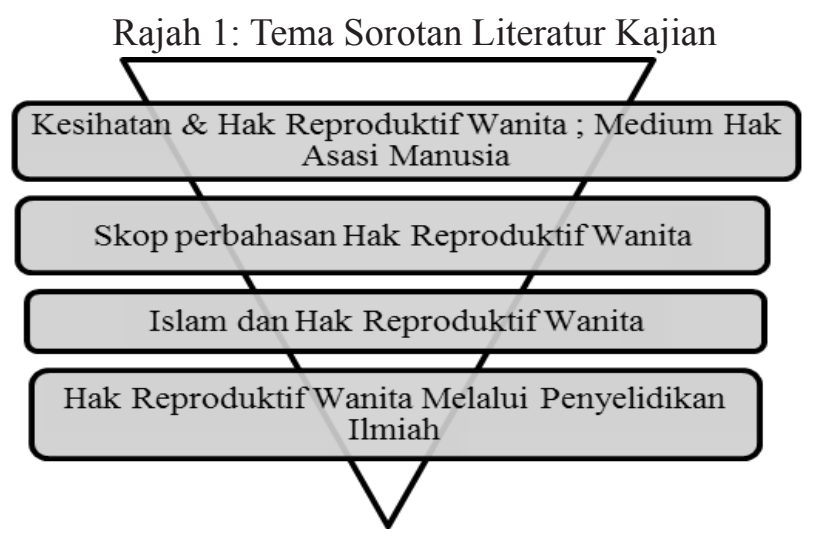

Sumber: Penulis

\section{KESIHATAN DAN HAK REPRODUKTIF WANITA SEBAGAI MEDIUM HAK ASASI}

Perbahasan tentang hak reproduktif wanita banyak diperjuangkan oleh sarjana di negara barat, atas dasar kepekaan mereka yang sangat tinggi dalam memperkasakan hak wanita. Bermula dengan cetusan awal untuk peningkatan status wanita antarabangsa sejak tahun 1900 melalui medan forum, sehingga 
timbul syor berkaitan pada tahun 1967 yang seterusnya membawa kepada cetusan idea CEDAW juga pada tahun yang sama tetapi hanya diratifikasi pada tahun 1980.

Kimala (2010: 50) dan Khanna (1992: 5) menyimpulkan kesihatan reproduktif ini sebagai satu bahagian yang akan melengkapi fizikal, mental dan kesejahteraan sosial. Ianya bukan sahaja melenyapkan penyakit atau ketidakcergasan dalam fizikal seseorang, tetapi merangkumi semua perkara yang berkaitan dengan sistem reproduktif sama ada fungsi dan juga prosesnya. Hak reproduktif pula melihat sejauh mana keadilan yang diperoleh wanita dalam menjalani setiap aktiviti kehidupannya bermula dengan kesihatan, seksualiti, dan sistem reproduktifnya. Oleh itu, hak reproduktif menekankan bahawa orang ramai khususnya wanita mampu untuk memiliki satu kehidupan seksual yang memuaskan dan selamat seterusnya berupaya untuk menentukan keproduktifannya secara bebas, bila dan bagaimana mereka melakukannya.

Dipersetujui Pillai dan Wang (1999: 10), Petchesky (2000: 9), Marge Berer (2004: 6) serta Chandiramani (2005: 130) bahawa golongan wanita seharusnya mencapai piawaian tertinggi bagi kesihatan seksual dan reproduktif mereka. Mengklasifikasikan hak reproduktif wanita sebagai suatu agenda adalah hak asasi bagi semua pasangan dan individu. Hal ini menuntut agar setiap keputusan dalam perihal seksual dan reproduktif ini diberikan sewajarnya kepada golongan wanita, terutama bagi memutuskan bilangan, jarak, dan tempoh yang sesuai untuk memiliki anak bagi memastikan berlakunya pemerkasaan wanita secara maksima. Ini secara tidak langsung menunjukkan bahawa keupayaan wanita untuk membuat dan melaksanakan keputusan mereka merupakan penentuan penting bagi kesihatan mereka.

Bagi Cervantes Carson (2002: 9), hak reproduktif seseorang wanita perlu dirangkumkan secara serentak di bawah dua kategori hak asasi manusia yang berbeza, iaitu hak individu dan hak sosial. Dalam memutuskan bagaimana, bila atau keadaan untuk memiliki anak adalah suatu penyataan mengenai hak individu dalam memilih reproduktifnya secara bebas, ianya bertitik tolak daripada konsep kebebasan individu, secara tidak langsung menunjukkan bahawa wanita itu berhak untuk mengawal tubuh badannya sendiri. Dalam masa yang sama, hak untuk akses kepada maklumat dan 'mengawal selia' tahap kesuburan seseorang itu merupakan satu penyataan mengenai hak untuk kebaikan sosial iaitu setiap individu wanita mempunyai hak untuk mendapat maklumat yang terkini dan tepat serta langkah yang lebih efektif dan selamat bagi mengawal selia kesuburan mereka. Sebagaimana dokumen Deklarasi Beijing pada tahun $1995^{1}$ menyatakan dengan jelas bahawa hak asasi manusia

UN Women, "Beijing Declaration and Platform for Action," http://www.un.org/ womenwatch/daw/cedaw/text/econvention.htm, dicapai pada 29 September 2015. 
bagi wanita meliputi hak mereka untuk mengawal tubuh badan mereka dan secara bebas membuat keputusan serta bertanggungjawab terhadap urusan yang berkaitan dengan seksualiti mereka.

Penetapan Correa (1997: 103), Pillai dan Wang (1999: 10) menegaskan agenda bagi kesihatan dan hak reproduktif pada peringkat asas adalah berkaitan kepuasan reproduktif dan keperluan seksual masyarakat, iaitu sejauh mana kawalan terhadap keputusan yang berkaitan dengan seksualiti dan reproduktif seperti perkahwinan, bila dan siapa yang terlibat dalam hubungan seksual, mengawal selia kesuburan yang bebas daripada ketidakpuasan atau kesan sampingan dari kontrasepsi yang membahayakan dan untuk mendapatkan akses kepada maklumat mengenai pencegahan dan rawatan bagi penyakit reproduktif dan kelahiran yang tidak selamat. Hal ini bertepatan dengan Program Aksi Seminar Antarabangsa tentang kependudukan dan pembangunan (ICPD) 1994 dan Persidangan Dunia Wanita di Beijing 1995, dimana perbahasan mengenai kesihatan reproduktif dan seksual wanita ini boleh dikira sebagai suatu persetujuan peringkat antarabangsa yang mendefinisikan hak seksual wanita meliputi hak mereka untuk menentukan dan mengawal segala aspek yang berkaitan dengan seksualiti mereka² (Arbaiyah, 2012: 14).

Walau bagaimanapun, Chrisler (2014: 205) berpandangan rata-rata wanita masih kurang menitikberatkan pengetahuan tentang isu ini kerana mereka menganggap bahawa peranan mereka hanya pada kewajipan-kewajipan yang khusus seperti menjadi seorang isteri terhadap suami, menjadi ibu kepada anak-anak, mengatur rumah tangga, berbanding peranan mereka terhadap diri mereka sendiri. Begitu juga dengan pandangan mereka terhadap erti sihat, mereka merasakan bahawa sihat itu hanya tertumpu pada keupayaan fizikal, ketiadaan penyakit semata-mata, sedangkan ianya jauh lebih luas daripada itu (Ibid).

\section{SKOP PERBAHASAN HAK REPRODUKTIF WANITA}

Ruang lingkup perbahasan hak kesihatan reproduktif saling berbeza mengikut pandangan setiap pengkaji. Juliandi (2010: 22) dan Yunita (2015: 8) menghuraikan ruang lingkup permasalahan reproduktif ini tidak hanya tertumpu pada masalah yang berkaitan dengan kehamilan, kemandulan,

2 Carolyn Frohmader \& Stephanie Ortoleva (2013), "The Sexual and Reproductive Rights of Women and Girls with Disabilities," ICPD Beyond 2014: International Conference On Human Rights, http://wwda.org.au/wp-content/uploads/2013/12/ issues_paper_srr_women_and_girls_with_disabilities_final.pdf, dicapai pada 22 Disember $20 \overline{1} 7$. 
kelahiran, tetapi lebih luas kepada proses perancangan keluarga kerana memberikan kesinambungan hubungan terhadap pengurangan kadar kematian bayi, kesihatan bayi dan anak-anak. Hubungan ini dilihat apabila mereka menitikberatkan isu kesihatan reproduktif, secara tidak langsung ianya dapat mengurangkan komplikasi yang berlaku disebabkan kehamilan dan kelahiran, sepertimana yang banyak berlaku di beberapa negara barat seperti Nigeria yang sangat berisiko dalam kes kehamilan tidak diingini, kematian disebabkan kehamilan, komplikasi pengguguran yang tidak selamat (Adenike, 2017: 8).

Seiringan Juliandi, terdapat pengkaji lain turut berpendapat yang sama bahawa isu perancangan keluarga menjadi fokus keutamaan dalam hak reproduktif wanita. Antaranya Mueller (1993: 269), Theresse (2011: 2) Idda Mosha (2013: 2), Mwenegoha (2008: 36), Alvarez-Nieto (2015: 80), Henri (2016: 332) dan juga pengkaji-pengkaji peringkat dalaman seperti Harlina (2009: 53) dan Sri Rahayu (2013: 35). Mereka berpendapat bahawa kesihatan reproduktif yang relevan adalah berkait dengan perlaksanaan perancangan keluarga yang profesional merangkumi sikap dan tingkah laku seksual wanita dan pasangan dalam mempengaruhi penerimaan, pilihan dan penggunaan kontraseptif yang berkesan.

P. David (1990: 5) beranggapan bahawa perancangan keluarga sebagai suatu cara yang sangat efektif dalam mengurangkan kelahiran dan seterusnya mengawal kadar ferteliti (Sri Rahayu, 2013: 35) seseorang. Penurunan kadar ferteliti boleh membawa kepada kesan penurunan terhadap pertumbuhan populasi yang terlalu meningkat dengan mendadak. ${ }^{3}$ Ianya juga dilihat sebagai suatu perkara yang harus diketahui dan diambil berat oleh masyarakat umum kerana kesannya akan berkait rapat dengan hal kesihatan ibu dan juga anak yang dilahirkan (Beegle, 2014: 26).

Kebanyakan negara sudah mula menggiatkan usaha melaksanakan pelbagai program khusus yang membincangkan tentang kesihatan wanita untuk memberikan kesedaran kepada masyarakat tentang pentingnya menjaga kesihatan diri. Farzaneh Roudi Fahimi (2004: 5) mengulas mengenai pentingnya perancangan keluarga untuk difahami oleh semua golongan masyarakat kerana ianya sebagai suatu usaha untuk mengurangkan kadar populasi bagi meningkatkan taraf hidup masyarakat meliputi aspek kesihatan, pendidikan dan hak yang sepatutnya diperolehi oleh isteri dan anak.

Ini juga dapat dilihat dalam usaha negara Indonesia memainkan peranan mereka untuk memperkenalkan perancangan keluarga di peringkat nasional apabila suatu ketika dahulu perancangan keluarga itu dikategorikan sebagai

3 Population Reference Bereau (1980), "World Population Data Sheet," Washington, D.C., http://www.prb.org/Publications/Datasheets.aspx, dicapai pada 20 Januari 2014. 
suatu yang dilarang sama sekali dan isu yang sensitif, tetapi tidak lagi pada ketika ini kerana usaha besar-besaran mereka memperkenalkan kaedah perancangan keluarga ini telah menanamkan kesedaran dalam kalangan masyarakat bahawa anak yang ramai bukan ukuran bagi keluarga yang hebat, akan tetapi lebih memandang kepada kualiti setiap anak yang dilahirkan sepertimana pandangan Utomo (2006: 75). Kini, lebih daripada 2/3 pasangan di Indonesia mengaplikasikan kaedah-kaedah moden kontraseptif dan jumlah selebihnya pula sudah memperlihatkan kesan ke arah perubahan tersebut (Ibid: 80). Perlakuan ini jelas menunjukkan suatu perubahan yang sangat positif dalam kalangan masyarakat Indonesia terhadap penerimaan perancangan keluarga. Hamijoyo (1994: 28) mengatakan bahawa antara faktor kejayaan terhadap penerimaan perancangan keluarga adalah disebabkan usaha dalam mempromosikan amalan perancangan keluarga yang sangat giat dijalankan oleh sukarelawan yang tidak berbayar di setiap kawasan perkampungan. Sukarelawan tersebut memainkan peranan dalam menyediakan servis-servis kebajikan keluarga seperti membekalkan bekalan kondom, pil-pil kontraseptif, khidmat nasihat perancang kehamilan terhadap wanita dan juga kesihatan anak.

Usaha yang dilakukan ini tidak lain hanya untuk memastikan aspek perancangan keluarga ini dititikberatkan dalam sebuah penyusunan keluarga bagi memastikan kesejahteraan diri wanita tersebut. Sebagaimana Mesganaw (2006: 62) dalam kajiannya mendapati, golongan yang tidak mengamalkan konsep perancangan keluarga kebiasaannya akan terdedah dengan pelbagai jenis komplikasi terhadap wanita dan juga bayi. Penilaian beliau juga mendapati antara sebab kelompok yang tidak merancang kehamilan ini berikutan kurangnya pendedahan terhadap perkara ini dan selebihnya sememangnya mahukan anak yang ramai. Berbeza dengan penerimaan masyarakat di Turkey, Pakistan, dan India melalui dapatan Sahin (2003: 10), Haque (2001: 95) dan Chandick (2003: 303) yang mana wanita di negara-negara ini mempunyai konflik di antara pasangan suami isteri dalam mengamalkan perancangan keluarga kerana persepsi negatif suami mereka terhadap amalan ini adalah bercanggah dengan budaya mereka.

\section{ISLAM DAN HAK REPRODUKTIF WANITA}

Perbincangan hak reproduktif wanita juga turut dititikberatkan oleh Islam kerana Islam memberikan setiap wanita hak untuk memperoleh kesihatan yang terjamin, bermula daripada proses menstruasi sehinggalah kepada hubungan intim, kehamilan, dan kelahiran. Hal ini bukanlah semata-mata kerana hak reproduktif, tetapi kapasiti wanita itu sendiri sebagai seorang makhluk istimewa 
yang diciptakan mempunyai hak tersendiri pada dirinya. Sehinggakan ada pendapat yang mengatakan sungguhpun agama itu meletakkan kewajipan seorang isteri untuk melayani kehendak seksual suaminya, tetapi seandainya berhadapan dengan masalah yang melibatkan kesihatan, kewajipan ini boleh diketepikan (al-Shirazi, 1980: 303). Nataraj (1994: 153) yang mengkaji realiti harian yang dihadapi oleh wanita dalam menangani hak reproduktif mereka, mendapati bahawa masih terdapat ketidakadilan gender di kebanyakan negara membangun yang mana mereka ini tidak berkuasa ke atas hak reproduktif mereka.

Mengambil contoh Thailand, di mana peranan utama wanita adalah menjaga keluarga. Dilihat juga dari sisi kehidupan seksual, mereka terdedah kepada amalan seks yang tidak dilindungi, kehamilan dan kelahiran yang tidak menentu. Begitu juga Whittaker ${ }^{4}$ mendapati masih terdapat diskriminasi yang jelas terhadap wanita di Vietnam dari segi akses kepada perkhidmatan kesihatan reproduktif disebabkan oleh keadaan ekonomi dan hidup mereka. Beliau mendapati bahawa permasalahan gender masih lagi berkait rapat dalam penafian hak untuk mereka mempertahankan harga diri dan mendapat perkhidmatan. Keupayaan wanita untuk mengakses perkhidmatan mungkin dihadkan oleh "status" mereka dalam keluarga. Ramai wanita menjelaskan bahawa mereka perlu meminta keizinan suami mereka untuk mendapatkan setiap rawatan penjagaan. Tambahan pula mereka masih terikat dengan kepercayaan tradisi dan budaya yang menghalang mereka untuk merealisasikan hak reproduktif wanita.

Shahida Zaidi, Arulmozhi Ramarajan (2009: 151) membawakan perbezaan hak seksual dalam konteks agama yang pelbagai iaitu Hindu, Confucias, Judaism, Kristian dan juga Islam di mana bagi agama-agama tersebut mempunyai perbezaan yang sedikit dalam mempertahankan hak reproduktif wanita. Tidak pada agama Islam yang sememangnya sudah nyata mengambilkira setiap hak wanita dalam segenap aspek. Bagi ajaran Confucias, pegangan ini sangat berpegang dengan konsep ren ${ }^{5}$ iaitu salah satu daripada intipati penting dalam ajaran ini. Fahaman Confucias ini lebih berlandaskan kepada keinginan untuk mempertingkatkan moral dan etika.

$4 \quad$ M. Whittaker (2006), Rigths and Realities-Vietnames Women Speak, http://www. regional.org.au/au/mwia/papers/full/23_whittaker2.htm, dicapai pada 1 Oktober 2015.

5 Konsep ren biasanya dimaksudkan sebagai hubungan antara manusia, kemanusiaan yang benar dan sempurna, yang merupakan dasar etika dan politik dalam ajaran Confucias. Konsep ren ini menekankan pengajaran dalam mendidik moral individu yang dimulai dari keluarga, negara dan dunia. 
Melalui fahaman ini, terbentuk dua kesan terhadap kesihatan wanita dan statusnya pada masyarakat dan keluarga, iaitu wanita itu berhak untuk akses kepada mana-mana informasi berkaitan kesihatan dan penjagaan diri. Tetapi tidak pada perihal statusnya dalam keluarga apabila ajaran Confucias adalah suatu doktrin yang penuh dengan sikap prejudis terhadap persoalan 'gender' kerana menganggap status wanita ini sangat rendah berbanding lelaki. Lebih lagi melibatkan permasalahan 'fertiliti'. Sekiranya sesebuah keluarga itu tidak mempunyai zuriat, disebabkan permasalahan fertiliti, kebiasannya wanita akan menjadi punca permasalahan untuk dipersalahkan. Jelas ianya menunjukkan penafian terhadap hak reproduktif wanita itu sendiri.

Secara umumnya, perbincangan tentang hak reproduktif wanita dalam Islam ini menjurus kepada aspek-aspek yang menjadi ruang lingkup perjalanan hak reproduktif wanita itu sendiri. Aspek ini boleh dilihat pada skop yang menjadi perbahasan seperti penentuan perkahwinan, anjuran mu'āsharah bi al-ma 'rüf dalam seksualiti rumah tangga, dan juga perancangan keluarga.

\section{Penentuan Perkahwinan}

Anjuran Islam melarang untuk sesebuah perkahwinan itu dijalankan secara paksa ke atas anak gadisnya sepertimana firman Allah iaitu:

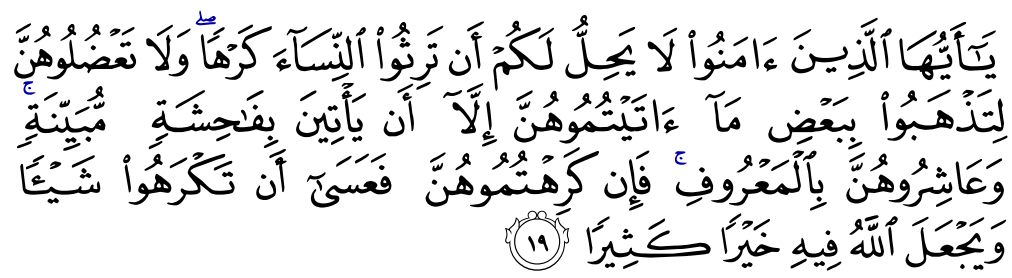

"Wahai orang-orang yang beriman, tidak halal bagi kamu mewarisi perempuan-perempuan dengan jalan paksaan, dan janganlah kamu menyakiti mereka (dengan menahan dan menyusahkan mereka) kerana kamu hendak mengambil balik sebahagian dari apa yang kamu telah berikan kepadaNya, kecuali (apabila) mereka melakukan perbuatan keji yang nyata. dan bergaullah kamu dengan mereka (isteri-isteri kamu itu) dengan cara yang baik. kemudian jika kamu (merasai) benci kepada mereka (disebabkan tingkah-lakunya, janganlah kamu terburu-buru menceraikannya), kerana boleh jadi kamu bencikan sesuatu, sedang Allah hendak menjadikan pada apa yang kamu benci itu kebaikan yang banyak (untuk kamu).'

(Surah al-Nisā', 4: 19) 
Menurut al-Shawkānī, ayat di atas menjelaskan bahawa Islam melarang seseorang wali melakukan penganiayaan terhadap anaknya dalam hal urusan pernikahan sehingga menyebabkan anaknya itu tidak mampu membuat keputusan sendiri sehingga menafikan hak anak mereka sebagai pembuat keputusan mutlak dalam kehidupan perkahwinan (al-Shawkān̄̄, t.t.: 707). Bukan itu sahaja, menurut Hamka, hak-hak golongan wanita juga perlu dilindungi dan mereka tidak boleh diperlakukan sewenang-wenangnya tanpa persetujuan mereka (Hamka, t.t: 300). Seiring dengan pendapat yang sama ialah pendapat daripada Imam Abu Hanifah, ulama' mazhab Hanafi, al-Awza'i, al-Thawri, Abu Ubayd, Ibn Munzir dan satu riwayat daripada pendapat Imam Ahmad menyatakan bahawa ayah atau wali lain tidak boleh atau tidak berhak memaksa anak perempuannya yang masih gadis untuk menikah dan jika hal ini berlaku maka pernikahan itu tidak sah (al-Qurtubi, 1995: 1241). Pendapatpendapat ini sangat bertepatan untuk diaplikasikan dalam zaman kontemporari ini dalam melihat pengiktirafan yang diberikan kepada seseorang wanita menentukan perkahwinannya.

Berbeza dengan beberapa pendapat yang masih terikat dengan kuasa wali seperti Imam Shāfi ’̀, Abu Laila, Ahmad dan Ishaq, mereka menyatakan bahawa datuk dan bapa kepada anak perempuan yang sudah mencapai usia baligh dan dewasa boleh memaksa anak perempuan itu untuk bernikah walaupun anak perempuannya itu menunjukkan rasa tidak puas hati atau membantah dengan keputusan walinya itu (al-Nawawi, t.th:169). Selepas ditarjih, dapat disimpulkan bahawa golongan jumhur ulama termasuk mazhab Shāfi' $\overline{1}$, Maliki dan sebahagian mazhab Hanbali berkenaan kahwin paksa oleh wali mujbir iaitu ayah kepada anak gadisnya yang sudah dewasa ('aqil baligh) dan masih gadis itu adalah dibolehkan. Namun mazhab Hanafi dan sebahagian mazhab Hanbali dan pendapat daripada Ibn al-Qayyim, tidak membolehkan hal tersebut.

\section{Seksualiti Rumah Tangga}

Menyentuh tentang hak suami isteri, sudah pasti setiap pasangan suami isteri akan mengimpikan satu hubungan yang harmoni, perlakuan yang baik di antara pasangan selari dengan hak-hak yang digariskan Islam dan juga hak semasa. Ini yang dikatakan sebagai anjuran dan tuntutan untuk mu 'āsharah bi al-ma 'rū f di antara suami isteri. Mu 'äsharah bi al-ma 'rūf adalah satu anjuran bagi suami untuk menggauli para isteri dengan baik. Tuntutan ini tidak lain tidak bukan bagi memastikan matlamat untuk mendapatkan perkahwinan yang 
sakinah, mawaddah dan warrahmah. Tuntutan ini sebagaimana firman Allah SWT dalam surah al-Nisā' ayat 19 yang menyatakan:

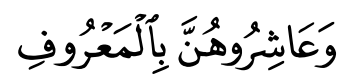

“... dan bergaulah kamu dengan mereka (isteri-isteri kamu itu) dengan cara yang baik...

(Surah al-Nisā’, 4: 19)

Imam al-Shawkani dalam tafsirnya menerangkan makna kalimah mu 'āsharah bi al-ma 'rūf ini dengan saranan untuk memperlakukan para isteri sebagaimana yang diperintahkan oleh Allah dengan cara yang baik, iaitu dengan memenuhi hak-haknya berupa mahar dan nafkah, dan baik dalam ucapannya.

Pada asasnya prinsip mu'āsharah bi al-ma 'rūf ini banyak dituntut dalam hubungan seksual di antara suami isteri. Tetapi mengambil pendekatan bahawa dalam perkahwinan, penjagaan hubungan yang harmoni bukan tertumpu keseluruhannya pada aspek seksual, bahkan menuntut kepada hubungan zahir yang lebih besar seperti nafkah, penjagaan kesihatan isteri, kehamilan dan kelahiran. Justeru, prinsip ini sangat sesuai untuk diperluaskan skopnya kepada setiap perbuatan yang baik, dan santun antara pasangan serta jauh dari segala bentuk kekerasan (Norzulaila, 2007: 19). Sekiranya berlaku kekerasan walau dalam apa bentuk sekalipun, maka secara jelas ia telah bertentangan dengan prinsip mu'āsharah bi al-ma'rüf.

\section{Kehamilan dan Kelahiran}

Proses kehamilan dan kelahiran suatu yang agak sinonim dengan golongan wanita yang berkahwin. Setiap daripada mereka perlu bersiap sedia dengan daya tahan yang kuat dari aspek mental dan fizikal bagi memastikan proses tersebut berjalan dengan lancar untuk kesihatan diri dan bayi yang dikandung. Budaya mengamalkan gaya hidup sihat dan menangani stress antara salah satu faktor yang boleh menjamin keseimbangan diri ketika hamil.

Melihat pengalaman di negara barat, dianggarkan setiap tahun kira-kira 210 juta wanita mengalami komplikasi kehamilan dan kelahiran yang mengancam nyawa dan kandungan. Tidak kurang juga bagi setengah juta wanita yang meninggal dunia ketika proses kehamilan dan melahirkan anak. Ini adalah salah satu kesan daripada keperluan kontraseptif yang tidak dipenuhi dan pengalaman menjalani kehamilan yang tidak diingini (lebih 80 juta wanita setiap tahun) (Glasier, 2006: 3). 
Apa yang penting dalam konteks menjaga hak reproduktif wanita ketika kehamilan dan kelahiran ini adalah dengan memberikan ruang yang sewajarnya kepada isteri bagi menentukan waktu dan masa yang dirasakan sesuai untuk mereka dari segi fizikal dan mental, khususnya untuk berhadapan dengan perjalanan kehamilan, seterusnya kelahiran. Ruang ini bukanlah memberikan keizinan mutlak kepada seorang isteri untuk mengawal suami, apatah lagi mengambil alih peranan suami sebagai ketua rumah tangga yang boleh membuat keputusan dengan sesuka hati. Akan tetapi, ruangan ini hanyalah sebagai salah satu usaha untuk memastikan perjalanan kehamilan dan kelahiran yang akan dihadapi kelak adalah dengan cara yang terkawal tanpa sebarang tekanan.

Hal ini kerana kedua-dua proses tersebut dianggap sebagai suatu kelemahan yang berganda (وهنا على وهن) seperti mana yang terkandung dalam al-Quran sepertimana berikut:

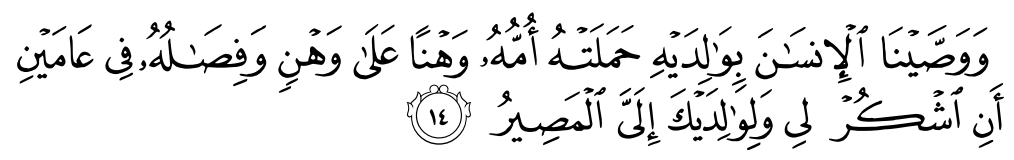

"Dan kami perintahkan kepada manusia (berbuat baik) kepada dua orang ibu-bapanya, ibunya telah mengandungnya dalam keadaan lemah yang bertambah-tambah, dan menyusukannya dalam dua tahun... bersyukurlah kepadaku dan kepada dua orang ibu bapamu, hanya kepada-Kulah kembalimu..."

(Surah Luqman, 31: 14)

Turut terkandung ibrah yang sama dalam surah al-Ahqaf ayat 15:

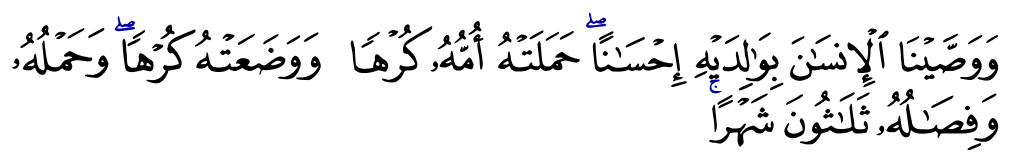

"Kami perintahkan kepada manusia supaya berbuat baik kepada dua orang ibu bapanya, ibunya mengandungnya dengan susah payah, dan melahirkannya dengan susah payah (pula)... mengandungnya sampai menyapihnya adalah tiga puluh bulan..."

(Surah al-Ahqaf, 46: 15)

Kedua-dua ayat ini mengandungi ibrah yang sangat besar apabila menggambarkan keperitan yang ditanggung oleh seorang ibu untuk berhadapan dengan situasi mengandung dan melahirkan anaknya. Oleh yang demikian, menjadi kewajipan bagi seseorang anak untuk meletakkan ketaatan yang 
tidak berbelah bahagi pada ibu yang telah mengandungkannya. Hal ini sesuai dengan darjat yang telah diletakkan oleh Islam antara kehormatan terhadap ibu dan juga bapa.

\section{Pengguguran}

Amalan pengguguran merujuk kepada suatu proses untuk menyingkirkan embrio atau fetus dari uterus ibu sebelum cukup bulan, sama ada secara spontan atau pun taruhan. ${ }^{6}$ Perbuatan sebegini memberikan implikasi hukum yang berbeza, bergantung kepada alasan dilakukan sama ada mengelakkan daripada berlakunya sesuatu kemudaratan yang lebih besar, mahupun untuk menolak kehamilan yang tidak diingini. Bagi proses pengguguran yang dijalankan tanpa sebarang sebab yang munasabah mengikut syarak, hukumnya adalah haram secara qaț $i$.

Amalan pengguguran yang dibenarkan di sisi Islam adalah melihat kepada mudarat yang timbul, contohnya apabila taraf kesihatan ibu tersebut tidak mampu untuk menampung kehamilan tersebut. Hal ini seterusnya mengakibatkan kondisi ibu tersebut dalam keadaan bahaya. Maka dalam hal ini, kaedah umum syariat iaitu الضرر الأشد يزال بالضرار الأخف membenarkan untuk melakukan mudarat yang lebih ringan bagi mengelakkan mudarat yang lebih besar (Nazar, 1993: 134).

Walau bagaimanapun, kelonggaran tersebut masih lagi tertakluk kepada syarat usia kandungan yang tidak melebihi 120 hari (Ibn 'Ābidin, 2003: 336). Ini berpandukan kesepakatan para ulama' fiqh yang berpegang bahawa pengguguran anak selepas ditiupkan roh padanya adalah suatu kesalahan yang berat dan haram (Ibn 'Ābidin, 2003: 336). Ini kerana apabila janin tersebut telah membentuk rupa seorang manusia, maka pengguguran tidak boleh dilakukan walaupun pada asasnya untuk kesihatan si ibu (Baharuddin, 2017: 70-71; al-Bakri, 2014: 374; Makiah, 2012: 75).

Adapun pengguguran bagi janin yang telah ditiupkan roh, iaitu sudah melepasi tempoh 120 hari, terdapat pandangan beberapa ulama' kontemporari (Shaltut, 1966: 289; al-Bakri, 2014: 374) yang membenarkannya, dengan syarat ia adalah jalan terakhir yang ada untuk menyelamatkan nyawa si ibu daripada kematian, dan dibuktikan secara medikasi daripada pakar perubatan yang bertauliah. Hal ini kerana menjaga kehidupan yang yakin adalah

6 Kamus Dewan Bahasa \& Pustaka, http://prpm.dbp.gov.my/Cari1 ?keyword=peng guguran\&d=129316\&, dicapai pada 5 September 2017. 
keutamaan berbanding kehidupan janin yang masih belum pasti (T.p., 1998: 57). Ini sebagaimana firman Allah SWT dalam al-Quran:

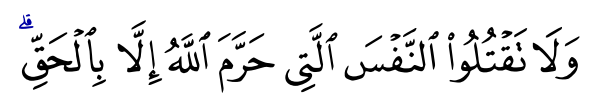

"Dan janganlah kamu membunuh jiwa yang diharamkan Allah (membunuhnya), melainkan dengan suatu (alasan) yang benar..."

(Surah al-Isrā', 17: 33)

Manakala, bagi kes pengguguran yang berlaku sebelum tempoh 120 hari, para fuqaha' memberikan pelbagai pandangan berbeza, antaranya seperti berikut:

Pendapat pertama: Pengguguran janin sebelum berlakunya proses peniupan roh adalah dibolehkan bagi sebahagian pendapat ulama' dari mazhab Hanafī, Shāfi' $\overline{1}$ dan Hanbalī dan Mālik̄̄. ${ }^{7}$ Mereka berdalilkan hadis Ibn Mas 'ud yang menunjukkan bahawa roh belum ditiup ke dalam janin dan penciptaan masih lagi belum sempurna sebelum empat bulan sebagaimana berikut:

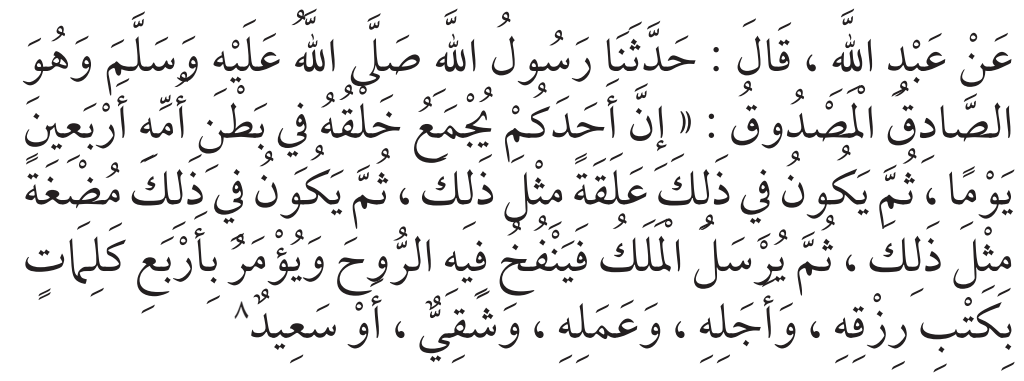

"Dari 'Abd Allah bin Mas 'ud, dia berkata: Telah berkata kepada kami Rasulullah SAW, dan dia adalah orang yang jujur lagi dipercayai: "Sesungguhnya tiap kalian dikumpulkan ciptaannya dalam rahim ibunya, selama 40 hari berupa nutfah (air mani yang kental), kemudian menjadi 'alaqah (segumpal darah) selama itu juga, lalu menjadi mudghah (segumpal daging) selama itu,

\footnotetext{
Antara ulama yang membenarkan adalah Imam Ibn 'Abidin, Imam Abu al-Hassan al-Lakhmiy, dan Ibn Qudamah. Hal ini dipersetujui apabila terdapat alasan yang kukuh untuk melakukan pengguguran tersebut dan sebelum berlakunya persenyawaan bagi Ibn Qudamah.

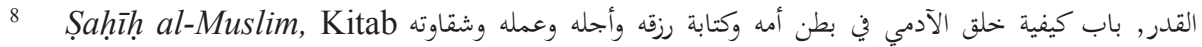

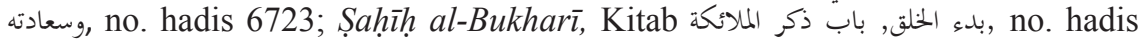

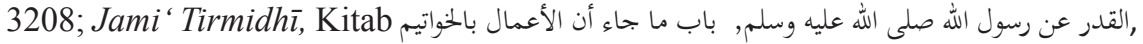

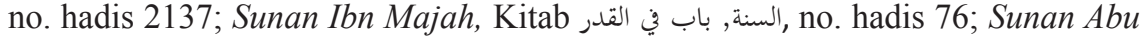
Dōwud, Kitab السنة, باب في القدر no. hadis 4708.
} 
kemudian diutus kepadanya malaikat untuk meniupkannya ruh, dan dia diperintahkan mencatat empat perkara yang telah ditentukan: rezekinya, ajalnya, amalnya, kesulitan atau kebahagiaannya.."

Pendapat kedua: Pengguguran pada tahap ini adalah makruh kerana mengambil kira waktu peniupan ruh yang tidak pasti, justeru perbuatan tersebut sebagai langkah berhati-hati. Pendapat ini dipegang oleh oleh sebahagian ulama' mazhab Hanafi dan juga sebahagian mazhab Shāfi'ī seperti Imam alRamly (Baharuddin, 2017: 70-71).

Pendapat ketiga: Pengguguran janin sebelum tempoh peniupan roh dikira sebagai haram. Implikasi ini berdalilkan logik bahawa tatkala berlakunya proses persenyawaan al-nutfah dan ovum yang dikenali dengan al-nutfah, bermakna sudah bermula saat untuk menerima kehidupan. Perbuatan merosakkan kewujudan tersebut dikira sebagai suatu perkara yang sangat keji. Pendapat ini dipegang oleh sebahagian mazhab Maliki iaitu Imam al-Dardir, sebahagian mazhab Shāfi‘i iaitu Imam Ghazali dan juga Ibn Qudamah dari mazhab Hanbali.

Ironinya, pengguguran ini hanya boleh dilakukan apabila bertembung antara dua mudarat, bagi menyelamatkan mudarat yang lebih besar, maka di situlah rukhsah pengguguran boleh dilakukan sebagaimana yang dijelaskan sebelum ini. Dengan syarat, kemudaratan tersebut diperakui oleh pakar perubatan yang bertauliah, dan keselamatan ibu dijamin dengan cara pengguguran sahaja.

Sepertimana fatwa yang telah dikeluarkan Muzakarah Jawatankuasa Fatwa Majlis Kebangsaan Bagi Hal Ehwal Agama Islam Malaysia Kali ke-26 Mac 1990 telah membincangkan berkaitan proses pengguguran disebabkan kecacatan yang timbul. Keputusan muzakarah menetapkan bahawa haram menggugurkan janin di dalam kandungan, kecuali atas sebab-sebab kecacatan yang teruk yang boleh membahayakan nyawa ibu. ${ }^{9} \mathrm{Hal}$ ini bertepatan dengan penetapan fatwa terbaru yang dikeluarkan oleh Mufti Wilayah Persekutuan Kuala Lumpur, berkaitan pengguguran yang dibolehkan disebabkan virus zika yang melanda negara suatu ketika. ${ }^{10}$

9 Jabatan Kemajuan Islam Malaysia (2015), Kompilasi Pandangan Hukum Muzakarah Jawatankuasa Fatwa Majlis Kebangsaan Bagi Hal Ehwal Agama Islam Malaysia. Putrajaya: Jabatan Kemajuan Islam Malaysia, 137.

10 Zulkifli Mohamad Al-Bakri (2016), "Hukum Berkaitan Virus Zika," Bayan Linnas, http://www.muftiwp.gov.my/index.php/ms-my/perkhidmatan/bayan-linna s/1243-bayan-linnas-siri-68-hukum-hukum-berkaitan-virus-zika, dicapai pada 12 September 2017. 


\section{Perancangan Keluarga}

Sejauh mengangkat permasalahan perancangan keluarga ini tidak ada nas yang jelas dalam al-Quran tentang pelarangan suami isteri untuk menjarakkan kehamilan, mengatur keluarga, mengurangkan bilangan zuriat selari dengan kemampuan fizikal, dan ekonomi keluarga mereka. Hal ini terpakai pada sebarang kaedah kontraseptif sama ada kaedah tradisional iaitu al-'azl mahupun kontraseptif moden yang lain. Kaedah moden seperti mana kaedah yang ada di pasaran masa kini, manakala bagi kaedah tradisional iaitu al- 'azl, secara tekniknya, digunakan untuk menjelaskan proses penarikan oleh kaum lelaki pada ketika pengeluaran sperma (ejakulasi) bagi mengelakkan terjadinya pembuahan pada ovum (sel telur) (Akhter, 1973: 63).

Menurut Syeikh Muhammad Amin al-Shanqiti, sebahagian ulama' berpegang kepada firman Allah SWT dalam surah al-An'am ayat $151^{11}$ sebagai ayat larangan untuk melakukan al- 'azl kerana dianggap sebagai pembunuhan anak secara tersembunyi (al-Shanqiti, 2005: 328). Menurut al-Shawkani, al'azl merupakan pembunuhan secara tersembunyi kerana wujudnya niat untuk menghindari kehamilan (al-Shawkani, 2006: 305).

Menurut Hamka, tiada larangan yang jelas tentang proses al-'azl dalam Islam kerana tidak mempunyai dalil yang kuat. Beliau mengkategorikan hal ini sebagai urusan dalam urusan rumah tangga yang tidak perlu dihebohkan kerana bimbang akan menjejaskan institusi rumah tangga itu sendiri (Hamka, t.t: 104). Sungguhpun begitu, beliau lebih cenderung dengan tidak bersetuju atas perlaksanaan perancangan keluarga ini kerana boleh memberikan pengaruh negatif terhadap kesihatan mental dan kemerosotan moral dalam hidup berkeluarga (Hamka, t.t.: 104).

Terdapat pandangan daripada ulama lain yang menyatakan bahawa al- 'azl sebenarnya dibolehkan, tetapi dianggap sebagai suatu amalan yang tidak patut (makruh). Hal ini adalah kerana ianya seakan menghapus hak seorang wanita untuk merasakan kepuasan seksual dan memiliki anak (al-Jawziyyah, 1960: 21). Sungguhpun ada yang mengatakan amalan ini sebagai makruh, tetapi dalam banyak keadaan pada masa kini, ianya sudah menjadi suatu kebiasaan dan keharusan, terutama apabila melibatkan hak reproduktif wanita itu sendiri yang perlu dijaga rapi. Ianya melibatkan keadaan seperti risiko yang akan dihadapi oleh isteri dalam mendepani kehamilan, menanggung beban yang berlebihan dalam kelahiran yang berterusan dan juga kesulitan ekonomi

11 وَ.... (Surah al-An‘ām, 6: 151)

"Dán janganlah' kamu membunuh anak-anak kamu kerana takut kemiskinan, Kami akan memberi rezeki kepadamu..." 
keluarga. Justeru, kontrasepsi secara $a l$ - 'azl itu dibolehkan dengan mengambil kira prinsip darurat (al-Ghazali, t.t.: 1302). Prinsip ini akan mengimbangi di antara keselamatan isteri dan kesihatan tubuhnya.

\section{HAK REPRODUKTIF WANITA MELALUI PENYELIDIKAN ILMIAH}

Perbincangan tentang hak reproduktif wanita dalam kajian dan penyelidikan terdahulu sememangnya banyak dijalankan, terutamanya di peringkat antarabangsa. Antaranya ialah kajian Bidney (2017: 800), Pillai (2011: 2), Nowicka (2011: 119) yang mana masing-masing menjelaskan tentang isu hak reproduktif dan hak asasi manusia di negara masing-masing melalui pendekatan yang berbeza. Isu hak reproduktif yang dibawakan oleh pengkaji terdahulu kebanyakannya melihat kepada perlaksanaan masyarakat dalam mengintegrasikan hak asasi, hubungan seksual, dan kesihatan reproduktif dalam memperkasakan hak reproduktif wanita.

Manakala antara kajian yang membincangkan skop perbahasan yang menjurus kepada pengamalan semasa hak reproduktif wanita boleh dirujuk pada kajian Browne (2012: 18) yang membincangkan bagaimana pengamalan hak reproduktif dalam kalangan wanita di Senegal dan Cameroon. Hasil dapatan beliau juga turut menuntut kepada suatu usaha berterusan bagi lebih memperkasakan pengetahuan dan amalan hak reproduktif wanita, terutama dalam aspek penggunaan kontraseptif. Kajian lain pula seperti Irma Rayani (2016: 5), Dixon (2009: 23), Amanullah (1996: 3), Flegal (2013: 4), dan Fowler (2013: 33) membincangkan pengamalan hak reproduktif di kawasan kajian pilihan mereka, tetapi mengambil kira aspek yang berbeza-beza. Kajian Irma Rayani lebih kepada melihat pandangan Islam tentang seksualiti dan pengamalan semasa masyarakat. Beliau juga mengetengahkan faktor persekitaran yang membantu dalam melaksanakan seksualiti mengikut landasan syarak.

Dixon pula mengkaji reproduktif dalam kalangan wanita yang belum berkahwin, melihat kepada tahap fasiliti dan aksesebiliti di sekitar mereka melalui penglibatan badan-badan yang bertanggungjawab mengawal selia pengamalan reproduktif wanita. Manakala bagi Amanullah, Flegal dan Fowler, kajian mereka lebih kepada perbincangan tentang sejauh mana keupayaan seorang wanita dalam membuat keputusan untuk hak reproduktif diri mereka. Sungguhpun sasaran kajian mereka berbeza, ada dalam kalangan wanita yang menjadi penghuni penjara, penganut kepada sesebuah gereja, dan juga masyarakat antara tiga agama yang berbeza, tetapi hasil dapatan mereka boleh diklasifikasikan sebagai arah yang sama, di mana tahap perlaksanaan terhadap hak reproduktif wanita ini harus dipertingkatkan. 
Sarjana lain seperti Lu Weiqun (2008: 42) dan Yahya Khamis Ahmed Almualm (2007: 6), walaupun asasnya mengetengahkan tentang hak reproduktif wanita, tetapi perbincangannya lebih menjurus kepada skop perbahasan yang berkait tentang perancangan keluarga sahaja, dalam menilai dari aspek pengetahuan dan pengamalan perancangan keluarga itu sendiri.

Secara kesimpulannya, berdasarkan kepada kajian dan penyelidikan terdahulu, penulis mendapati masih kurang perbincangan yang mengkhususkan secara terperinci terhadap perbincangan tentang hak reproduktif wanita berkahwin merangkumi dari proses permulaan mereka menentukan pasangan sehingga membawa kepada perkahwinan, kehamilan, perancangan keluarga, kelahiran, pengguguran dan keganasan rumah tangga, terutamanya dalam konteks pengamalannya dalam kalangan masyarakat. Walaupun secara tidak langsung sebenarnya kajian yang dijalankan itu dilihat sasarannya pada golongan wanita berkahwin, tetapi huraian secara spesifik menjurus kepada perbahasan skop hak reproduktif wanita berkahwin masih lagi kurang dalam arena penulisan dan penyelidikan berkaitan hak reproduktif wanita.

\section{PENUTUP}

Penulisan-penulisan yang sedia ada membincangkan berkenaan hak reproduktif wanita sebenarnya telah memberikan banyak gambaran tentang isu global ini dalam pelbagai dimensi perbincangan. Penulisan ini sebagai satu asas utama untuk memahami konsep hak reproduktif wanita berkahwin menurut garis panduan syariat Islam dan kepentingan untuk diamalkan dalam menjalani peranan seharian.

Secara ringkasnya, hak reproduktif wanita berkahwin adalah satu sisi yang memfokuskan kepada keadilan yang perlu diperolehi oleh golongan wanita berkahwin supaya tidak berlaku sebarang pengabaian terhadap diri mereka, hak sosial mereka dalam menjalani kehidupan seharian tidak kira apa jua peranan reproduktif mereka ketika itu sama ada sebagai isteri mahupun sebagai seorang ibu. Bagi mencapai matlamat ini, tahap pemahaman semaksima mungkin perlu digiatkan dalam kalangan masyarakat supaya kes-kes yang melibatkan pengabaian hak reproduktif wanita ini boleh dikurangkan.

\section{BIBLIOGRAFI}

'Abd al-Hamid Muhammad al-Ghazzalī (t.t.). Ihya' 'Ulūm al-Dīn, vol. 2. Qāhirah: al-Mat'abah al-Azhariyyah al-Mișriyyah, 52, 1302. 
‘Abd al-Mālik bin ‘Abd al-Karīm Amr Allāh (1983). Tafsīr al-Azhar. Jakarta : PT Pustaka Panjimas.

Al-'Allamah Muhammad Amin bin Muḥammad Mukhtār al-Shanqitī (2005). Adwa' al-Bayān fì 'Iddah al-Qur'ān bi al-Qur'ān, vol. 2. Jeddah: Dār al-'Ilm Fawā'id.

Abū Ishāq Ibrāhim Ibn 'Alī Ibn Yūsuf al-Firuzabadī al-Shīraz̄i (1980). alMuhadhdhab fì Fiqh al-Imām al-Shāfi ‘’ vol. 2. Bayrūt: Dār al-Fikr.

Akhter Hameed Khan (1973). "Islamic Opinion on Contraceptive." dalam Muslim Attitudes Toward Family Planning. New York: The Population Council.

Alejandro Roberto Cervantes-Carson (2002). Human rights, reproductive rights, and population policies: a theoretical intervention, an analytical proposal, and an application to the case of Mexico. Austin: University of Texas.

Amanullah Khan (1996). Reproductive Decision Making Within Muslim Families in Squatter Settlements of Karachi. Pakistan: Aga Khan University.

Anna Glasier, A Metin Gulmezoglu, George P Schmid, Claudia Garcia Moreno, Paul FA Van Look (2006). "Sexual and Reproductive Health: A Matter of Life and Death," dalam The Lancet Sexual and Reproductive Health Series. New York: World Health Organization.

Badan Berkoordinasi Keluarga Berencana Nasional (BKKBN) (1997). Pedoman dan Klasifikasi Institusi Masyarakat Perdesaan. Jakarta: BKKBN.

Baharuddin, Ahmad Syukran (2017). "Jenayah Pengguguran Janin,” dalam Majalah al-Ustaz, Isu 60. Kuala Lumpur: Telaga Biru Sdn. Bhd.

Bidney, Sarah Combellick (2017). "Reproductive Rights as Human Rights: Stories from Advocates in Brazil, India and South Africa," The International Journal of Human Rights, vol. 21, no. 7, 800-822.

Browne, Alyssa (2012). "What's Religion got to do with it? Islam and Fertility in Senegal and Cameroon," (Research Honours Program) Cornell University.

Al-Būṭ̂̄, Muḥammad Sa'īd Ramaḍān (1991). Fiqh al-Sìrah al-Nabawī. Bayrūt: Dār al-Fikr al-Ma‘āsir.

Carmen Alvarez-Nieto et al. (2015). "Sexual and Reproductive Health Beliefs and Practices of Female Immigrants in Spain: A Qualitative Study," Reproductive Health Journal, vol. 12. 
Casterline JB, Sathar ZA, Haque M. (2001). “Obstacles to Contraceptives Use in Pakistan: A Study in Punjab," Study in Family Planning, vol. 32, no. 2, 95-105.

Chandick N, Dhillon BS, Kambo I, Saxena NC. (2003). "Contraceptive Knowledge, Practices and Utilization of Services in the Rural Areas of India," Indian Journal of Medical Sciences, vol. 57, no. 7.

Chandiramani, Radhinika (2005). "Mapping the Contours: Reproductive Health and Rights and Sexual Health and Rights in India," dalam Where Human Rights Begin: Health, Sexuality and Women in the New Millenium, ed. W. Chavkin \& E. Chesler. New Brunswick, New Jersey and London: Rutgers University Press, 127-153.

Dixon Bester Jimmy-Gama (2009). "An Assessment of the Capacity of Facilitybased Youth Friendly Reproductive Health Services To Promote Sexual and Reproductive Health Among Unmarried Adolescents: Evidence From Rural Malawi," Ph.D Thesis, Queen Margaret University.

Farzaneh Roudi Fahimi (2004). Islam and Family Planning. Washington: Population Reference Bureau.

Flegel, Alison C. (2013). "Violation of Women's Reproductive Rights: The Doctrines, Laws, and Habits That Create the Foundation of Our Sexist Culture," Master Thesis, East Carolina University.

Fowler, Erin (2013). “Advancing Reproductive Rights in a Religious World: A Comparative Survey of Reproductive Rights in Poland, Indonesia and Israel," Tesis Sarjana, University of Toronto.

H. Nazar Bakry (1993). Fiqh \& Ushul Fiqh. Jakarta: PT Raja Grafindo Persada. Hamijoyo SS. Chauls D. (t.t.). Why Community Participation Succeeds in the Indonesian Family Planning Program. Jakarta: BKKBN.

Hamisa Omari Mwenegoha (2008). “Women's Reproductive Rights and Autonomy Under Islam As They Intersect with Human Rights Entitlements and Customary Norms and Practices in Tanzania: Lushoto as A Case Study," Master Dissertation, Faculty of Law, University of Zimbabwe.

Harlina Halizah Siraj (2009). Citra Wanita Kontemporari. Kuala Lumpur: JIMedia.

Henri Shalahudin (2016). "Wacana Kesetaraan Gender dalam Pemikiran Islam di Institusi Pengajian Tinggi Islam Negeri di Indonesia: Kajian Kes di Universitas Islam Negeri Sunan Kalijaga Yogyakarta," Tesis Kedoktoran, Akademi Pengajian Islam, Universiti Malaya. 
Henry P. David \& Janine M. Morgall (1990). "United States and Denmark: Different Approaches to Health Care and Family Planning," Studies in Family Planning, vol. 21, no. 1, 1-19.

Ibn al-Qayyim al-Jawziyyah (1960). Zaad al-Maad, vol. 4. Mișr: Matba'ah Muștafā al-Bābī al-Ḥalābī wa Awlāduhu.

Ibn 'Ābidīn, 'Alī Muḥammad Mu'awwadh (2003). Radd al-Mukhtār 'ala alDur al-Mukhtār (Hashiyah Ibn 'Ābidīn), tahqīq 'Adil Aḥmad 'Abd alMawjūd. Riyāụ: Dār 'Alam al-Kutub.

Idda Mosha et al. (2013). "Family Planning Decisions, Perceptions and Gender Dynamics among Couples in Mwanza, Tanzania: A Qualitative Study," BMC Public Health, vol. 13.

Imām Muḥy al-Dīn Abū Zakariyyā Yahyā bin Sharf al-Nawawī (t.t.). alMajmū' Sharh al-Muhazzab, vol. 16. Jeddah: Maktabah al-Irshād.

Irma Rayani (2016). “The Silent Desire: Islam, Women's Sexuality and the Politics of Patriarchy in Indonesia. Tesis Kedoktoran, School of Social Asian, University of Western Australia.

Iwu Dwisetyani Utomo, Syahmida S Arsyad, \& Eddy Nurul Hasmi (2006). "Village Family Planning Volunteers in Indonesia: Their Role in The Family Planning Programme," Journal of Reproductive Health Matters, 75-80.

J. Khanna, et al. (1992). Reproductive Health: A Key to Brighter Future. Biennial Report 1990-1991. Geneva: World Health Organization.

Jabatan Kemajuan Islam Malaysia (2015). Kompilasi Pandangan Hukum Muzakarah Jawatankuasa Fatwa Majlis Kebangsaan Bagi Hal Ehwal Agama Islam Malaysia. Putrajaya: Jabatan Kemajuan Islam Malaysia.

Joan C. Chrisler (2014). "A Reproductive Justice Approach to Women's Health," Analyses of Social Issues and Public Policy, vol. 14, no. 1, 205-209.

Juliandi Harahap (2010). Panduan Pendidikan Hak \& Kesehatan Reproduksi. Jakarta: Rahima.

Kamus Dewan Bahasa \& Pustaka (2017). http://prpm.dbp.gov.my/Cari1?key word=pengguguran\&d=129316\&, dicapai pada 5 September 2017.

Kathleen Beegle et al. (2014). Does Family Planning Reduce Fertility? Evidence from Rural Ethiopia. Washington DC: The World Bank.

Lu Weiqun (2008). Contraceptive Choice Among Married Women in Guizhou Province: Socio-Cultural and Relationship Factors. Pulau Pinang: Universiti Sains Malaysia. 
M. Whittaker (2006). "Rigths and Realities: Vietnames Women Speak," http:// www.regional.org.au/au/mwia/papers/full/23_whittaker2.htm, dicapai pada 1 Oktober 2015.

Mahmūd Shaltūt (1996). al-Islām 'Aqūdah wa al-Sharī'ah. Qāhirah: Dār alQalam.

Makiah Tussaripah Jamil Abdul Mukti Baharudin \& Hisam Satari (2012). "Pengguguran Bayi Menurut Perspektif Islam dan Perundangan di Malaysia," Global Journal al-Thaqafah, vol. 2, no. 1, 69-82.

Marge Berer (2004). "Sexuality, Rights and Social Justice," Journal of Reproductive Health Matters, vol. 12, no. 23, 6-11.

Mesganaw Fantahun (2006). "Comparative Study of the Characteristics of Family Planning Service Users and Non-Users in Northwest Ethiopia," African Journal of Reproductive Health, vol. 10, no. 1, 62-70.

Muḥammad bin Aḥmad bin Muḥammad Ibn Rushd al-Qurtubī (1995). Bidāyah al-Mujtahid wa Nihāyah al-Muqtașid, vol. 3. Qāhirah: Dār al-Salām.

Muhạmmad bin 'Alī al-Shawkānī (2006). Nayl al-Awțār min Asrār al-Muntaqa al-Akhbār, vol. 12. Bayrūt: Dār Ibn al-Jawzī.

Muḥammad bin 'Alī bin Muḥammad al-Shawkānī (t.t.). Fatḥ al-Qādir alJami' Bayna fì al-Riwāyah wa al-Dāriyah min 'Ilm al-Tafsīr. t.t.: t.t.p.

Nataraj S, Temba, M, Mangalas (1994). Private Decisions, Public Debate: Women, Reproduction, and Population. London: Panos Publications Ltd.

Norzulaili Mohd Ghazali (2007). Nusyuz, Syiqaq dan Hakam Menurut alQur'an, Sunnah dan Undang-Undang Keluarga Islam. Kuala Lumpur: Kolej Universiti Islam Malaysia.

Nowicka, Wanda (2011). "Sexual and Reproductive Rights and the Human Rights Agenda: Controversial and Contested," Reproductive Health Matters, vol. 19, no. 38, 119-128.

O. Esiet, Adenike (t.t.). "Adolescent Sexual and Reproductive Health in Nigeria," Action Health Incorporated.

Pillai, V. K. et al. (1999). Women's Reproductive Rights in Developing Countries. England: Ashgate Publishing Company.

Pillai, Vijayan \& Gupta, Rashmi (2011). "Reproductive Rights Approach to Reproductive Health in Developing Countries," Global Health Action, vol. 4, no. 1, 1-12.

Population Reference Bereau (1980). "World Population Data Sheet," Washington, D.C., http://www.prb.org/Publications/Datasheets.aspx, dicapai pada 20 Januari 2014. 
Price, Kimala (2010). "What is Reproductive Justice?: How Women of Color Activists Are Redefining the Pro-Choice Paradigm," Meridians, vol. 10, no. 2, 42-65.

Promoting Youth Health and Development (t.t.) https://www.wilsoncenter.org/ sites/default/files/Esiet\%20Presentation.pdf, dicapai pada 3 Februari 2017.

R. Petchesky (2000). Reproductive and Sexual Rights: Charting The Course of Transnational Women's NGOs. New York: United Nations Research Institute for Social Development.

Ruth Dixon, Mueller (1993). "The Sexuality Connection in Reproductive Health," dalam Studies in Family Planning, vol. 25, no. 5, 269-282.

Sahin HA. Sahin HG. (2003). "Reason for not using Family Planning Methods in Eastern Turkey," Eur J Contraceptive Reproductive Health Care, vol. 8 , no. $1,11-16$.

Shahidah Zaidi, Arulmozhi Ramarajan, Renzong Qiu, Michal Raucher, Ruth Chadwick \& Amna Nossier (2009). "Sexual Rights and Gender Roles in a Religious Context," International Journal of Gynecology and Obstetrics, 151-155.

Sonia Correa (1997). "From Reproductive Health to Sexual Rights Achievements and Future Challenges," Reproductive Health Matters, vol. 5, no. 10, 107-116.

Sri Rahayu Sanusi (2013). Kesihatan Reproduktif dalam Kalangan Wanita Miskin Bandar di Bandar Medan Sumatera Utara Indonesia. Kuala Lumpur: Universiti Malaya.

Therese McGinn et al. (2011). "Family Planning in Conflict: Results of CrossSectional Baseline Surveys in Three African Countries," Conflict and Health, vol. 5.

UN Women (2015). "Beijing Declaration and Platform for Action," http:// www.un.org/womenwatch/daw/cedaw/text/econvention.htm, dicapai pada 29 September 2015.

Wizārah al-Awqāf wa al-Shi'un al-Islamiyyah (1998). Mawsū'ah Fiqhiyyah. Kuwayt: Dār al-Ṣafwah.

Yahya Khamis Ahmed Al-Mualm (2007). Knowledge, Attitude and Practice of Husbands Towards Modern Family Planning in Mukalla, Yemen. Pulau Pinang: Universiti Sains Malaysia.

Yunita Miftahul Masita (2015). "Hak Reproduksi Pengaturan Jumlah Anak dan Pemilihan Alat Kontrasepsi," Tesis Sarjana, Program Pascasarjana Prodi Ilmu Kesehatan Masyarakat Universitas Sebelas Maret Surakarta. 
Yusuf al-Qaradhawi (2014). Halal dan Haram dalam Islam, terj. Zulkifli Mohamad al-Bakri. Negeri Sembilan: Pustaka Cahaya Kasturi Sdn Bhd.

Zulkifli Mohamad al-Bakri (2016). "Bayan Linnas: Hukum Berkaitan Virus Zika," http://www.muftiwp.gov.my/index.php/ms-my/perkhidmatan/ bayan-linnas/1243-bayan-linnas-siri-68-hukum-hukum-berkaitanvirus-zika, dicapai pada 12 September 2017. 